\title{
Economic Evaluation of Fiscal Regime on EOR Implementation in Indonesia: A Case Study of Low Salinity Water Injection on Field X
}

Adityawarman ${ }^{1}$, Faridh Afdhal Aziz ${ }^{1}$, Prasandi Abdul Aziz ${ }^{1}$, Purnomo Yusgiantoro ${ }^{1}$, Steven Chandra ${ }^{1 *}$ ${ }^{1}$ Department of Petroleum Engineering, Faculty of Mining and Petroleum Engineering, Institut Teknologi Bandung, Jalan Ganesha No 10 Bandung, Indonesia

*Corresponding Author: steven@tm.itb.ac.id

\begin{tabular}{l}
\hline Article History: \\
\hline Received: February 6, 2020 \\
Receive in Revised Form: April 21, 2020 \\
Accepted: April 22, 2020
\end{tabular}

Keywords:

Gross Split, Cost Recovery, Low Salinity Water Injection, Net Present Value

\begin{abstract}
There are currently two fiscal regimes designated for resource allocation in Indonesia's upstream oil and gas industry, the Production Sharing Contract Cost Recovery (PSC) and Gross Split. The Gross Split in the form of additional percentage split is designed to encourage contractors to implement Enhanced Oil Recovery (EOR) in mature fields. Low Salinity Water Injection (LSWI) is an emerging EOR technique in which the salinity of the injected water is controlled. It has been proven to be relatively cheaper and has simpler implementations than other EOR options in several countries. This study evaluates the LSWI project's economy using PSC and Gross Split and then to be compared to conventional waterflooding (WF) project's economy. There are four cases on Field $\mathrm{X}$ that are simulated using a commercial simulator for 5 years. The cases are evaluated under PSC and Gross Split to calculate the project's economy. The economic indicators that will be evaluated are the Net Present Value (NPV) and sensitivity analysis is also conducted to observe the change of NPV. The parameters for sensitivity analysis are Capital Expenditure (CAPEX), Operating Expenditure (OPEX), Oil Production, and Oil Price. It is found that LSWI implementation using Gross Split is more profitable than PSC. The parameters that affects NPV the most in all PSC cases are the oil production and oil price. On the other hand, in Gross Split cases, the oil production is the parameter that affects NPV the most, followed by oil price. The novelty of this study is in the comparison of project's economy between WF and LSWI using two different fiscal regimes to see whether Gross Split is more profitable than PSC on EOR implementation, specifically the LSWI at Field X.
\end{abstract}

\section{INTRODUCTION}

Indonesia's Ministry of Energy and Mining Resources issued Regulation No. 8 of 2017 (Permen ESDM No 08 Tahun 2017 Tentang Kontrak Bagi Hasil Gross Split, 2017) on January 13 ${ }^{\text {rd }}$, 2017 to introduce new fiscal regime in resource allocation in upstream oil and gas industry, the Gross Split, and the regulation was amended by Regulation No. 52 of 2017 (Permen ESDM No 52 Tahun 2017 Tentang Perubahan Atas Peraturan Menteri Energi dan Sumber Daya Mineral Nomor 08 Tahun 2017 tentang Kontrak Bagi Hasil Gross Split, 2017) to further improve the Gross Split scheme. It is a new oil and gas fiscal regime that the government hopes will restore investor's confidence to invest in Indonesia.

Before the Gross Split was introduced, the model used in Indonesia was Production Sharing Contract (PSC). The PSC was first implemented in Indonesia on August $18^{\text {th }}, 1966$ in respect of the Offshore Northwest Java Block between Pertamina and Independent Indonesian American Petroleum Company (Roach \& Dunstan, 2018).

One of the key differences between Gross Split and PSC is the split calculation between the contractors and the government. Gross Split have variable split and progressive split that adjust the base split, one of 
the variables is production stage. So, if a field is in the tertiary production stage, the Enhanced Oil Recovery (EOR) stage, the contractors will get more split percentage compared to field in the secondary production stage. One of the examples of secondary production stage is waterflooding (WF).

In the past, WF is largely designed without focusing on the composition of the injected water. Low Salinity Water Injection (LSWI) is an emerging EOR technique in which the salinity of the injected water is controlled to improve oil recovery. Core floods and other tests have indicated that changes in the injected water composition can improve basic waterflood performance by 5\% to 20\% (Dang, Nghiem, Nguyen, Chen, et al., 2015), thereby introducing the promising idea that the LSWI is an emerging EOR technique that is relatively cheaper and has simpler implementations compared to other EOR options.

LSWI has been proven as an emerging technique for improving oil recovery not only from laboratory scale (Hidayat et al., 2018; Marhaendrajana et al., 2018), but also shown on Table 1 a summary of field implementations of LSWI. Compared to the conventional WF and EOR methods, the major advantages of LSWI include considerable recovery benefit, lower cost and relatively simpler to implement, easier to be implemented in both onshore and offshore reservoirs, possible utilization of onsite facilities without requiring a large quantity of chemical or gas for EOR projects, and more environmentally friendly. However, LSWI is dependent on geological setting, Table 2 shows a pre-screening criterion in order to identify the most promising candidates for LSWI implementation (Dang, Nghiem, Nguyen, \& Chen, 2015).

Table 1. Summary of LSWI field implementation (Dang, Nghiem, Nguyen, \& Chen, 2015).

\begin{tabular}{|c|c|c|c|c|}
\hline Author & Reservoir & $\begin{array}{l}\text { Injected Brine/ } \mathrm{F} \\
\text { Water }(\mathrm{ppm})\end{array}$ & $\begin{array}{c}\text { FormationFormation } \\
\text { Damage }\end{array}$ & $\begin{array}{l}\text { Incremental } \\
\text { Recovery }(\%)\end{array}$ \\
\hline Webb (2004) & Sandstone & $3,000 / 220,000$ & No & 20 \\
\hline $\begin{array}{l}\text { McGuire } \\
(2005)\end{array}$ & $\begin{array}{l}\text { Sandstone } \\
<\text { Alaska North Slope> }\end{array}$ & $150-1,500 / 15,000$ & No & 13 \\
\hline $\begin{array}{l}\text { Robertson } \\
(2007)\end{array}$ & $\begin{array}{l}\text { Sandstone } \\
<\text { West Semlek Reservoir> } \\
<\text { North Semlek Reservoir> } \\
<\text { Moran Reservoir> }\end{array}$ & $\begin{array}{l}\text { 10,000/60,000 } \\
3,304 / 42,000 \\
7,948 / 128,000\end{array}$ & No & $\begin{array}{l}\text { Recovery tends to } \\
\text { decrease as the } \\
\text { salinity } \\
\text { increases }\end{array}$ \\
\hline Lager (2008) & $\begin{array}{l}\text { Sandstone } \\
<\text { Alaskan Oil Field> }\end{array}$ & $2,600 / 16,640$ & No & 10 \\
\hline $\begin{array}{l}\text { Veledder } \\
(2010)\end{array}$ & $\begin{array}{l}\text { Sandstone } \\
<\text { Omar Oil Field> } \\
<\text { Isa Oil Field > }\end{array}$ & $2,200 / 90,000$ & No & $10-15$ \\
\hline $\begin{array}{l}\text { Secombe } \\
(2010)\end{array}$ & $\begin{array}{l}\text { Sandstone } \\
<\text { Endicot Oil Field }>\end{array}$ & $12,000 /--$ & No & 13 \\
\hline $\begin{array}{l}\text { Skrettingland } \\
(2010)\end{array}$ & $\begin{array}{l}\text { Sandstone } \\
<\text { Snorre Oil Field }>\end{array}$ & $500 / 50,000$ & No & $\begin{array}{l}\text { No significant } \\
\text { change }\end{array}$ \\
\hline
\end{tabular}

Oil wet or mixed wet reservoir could be a good candidate for LSWI application. The reason for this important screening factor comes from the main mechanism of LSWI in which LSWI alters the wettability towards more water wet. Thus, a small modification on relative permeability curves in strong water wet reservoirs may not be enough for achieving enough incremental recovery. Figure 1 shows an example of the schematic shifting of relative permeability curves in LSWI and Figure 2 shows a result of incremental oil recovery by LSWI in preferential oil wet and water wet reservoirs. 
Table 2. Pre-screening conditions for LSWI implementations (Reproduced from Dang, Nghiem, Nguyen, \& Chen (2015)).

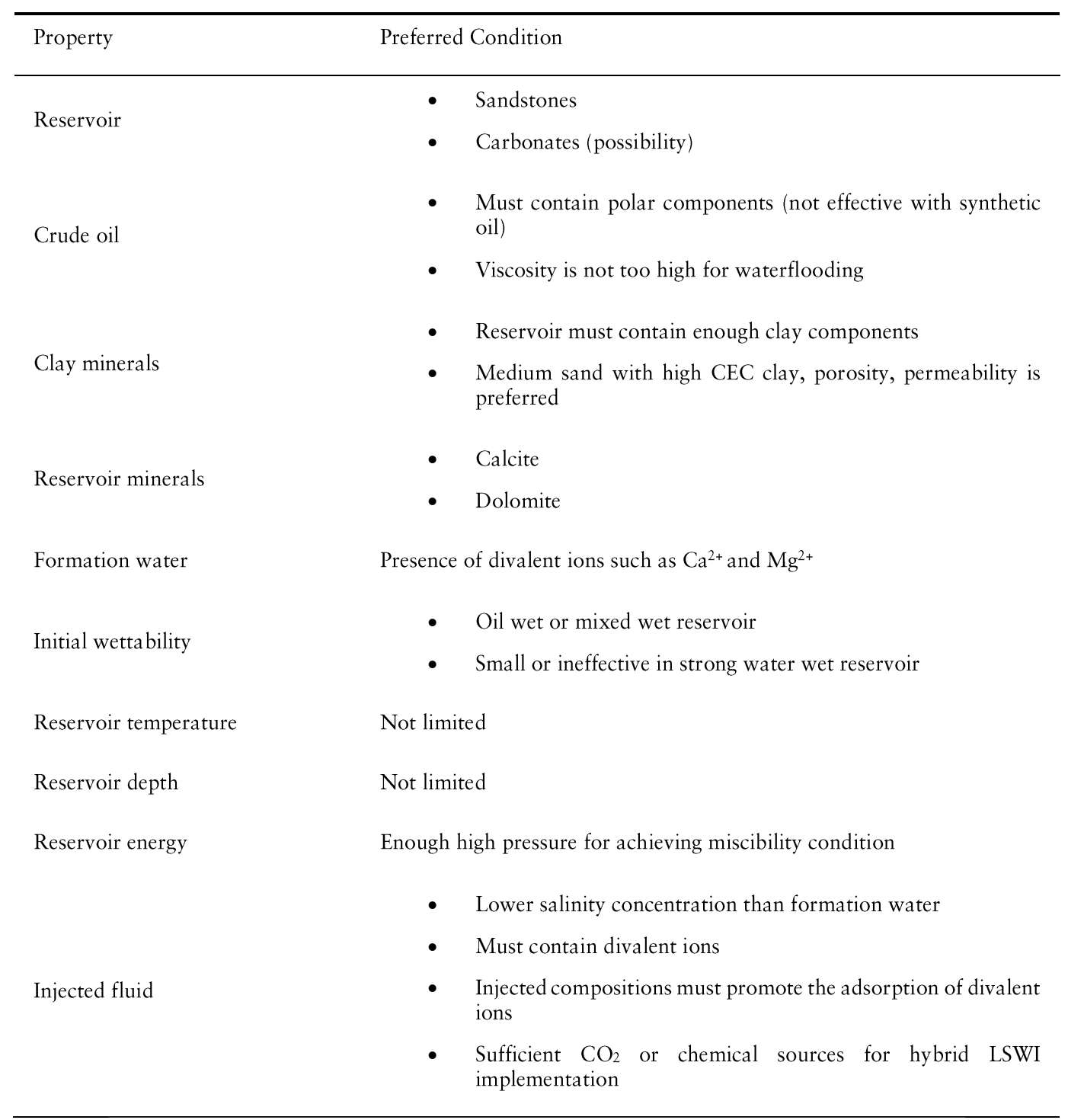

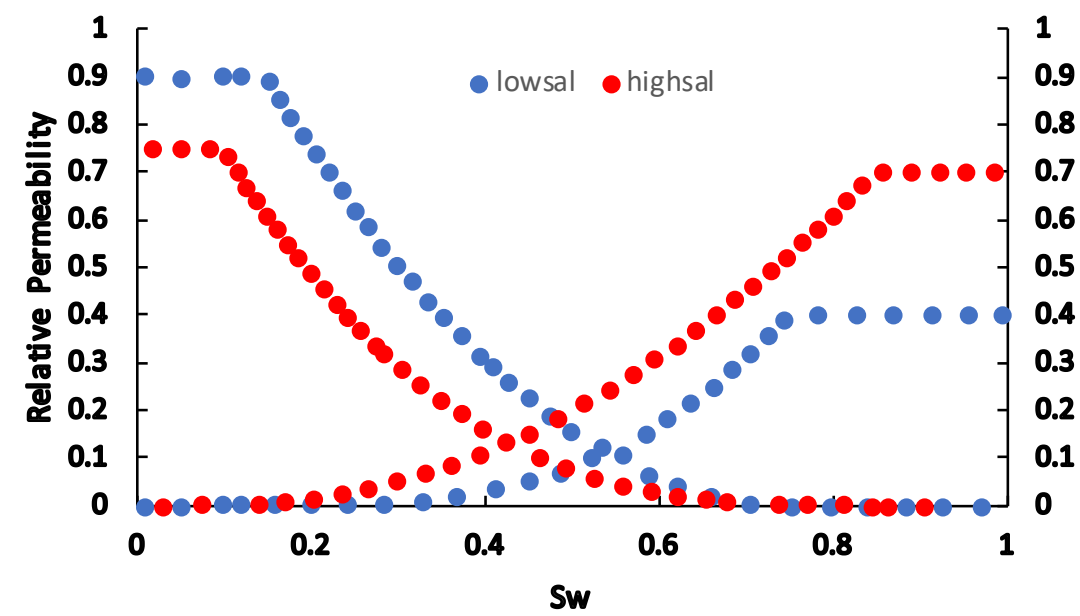

Figure 1. Schematic shifting of relative permeability curves in LSWI (Reproduced from Dang et al., (2013)). 


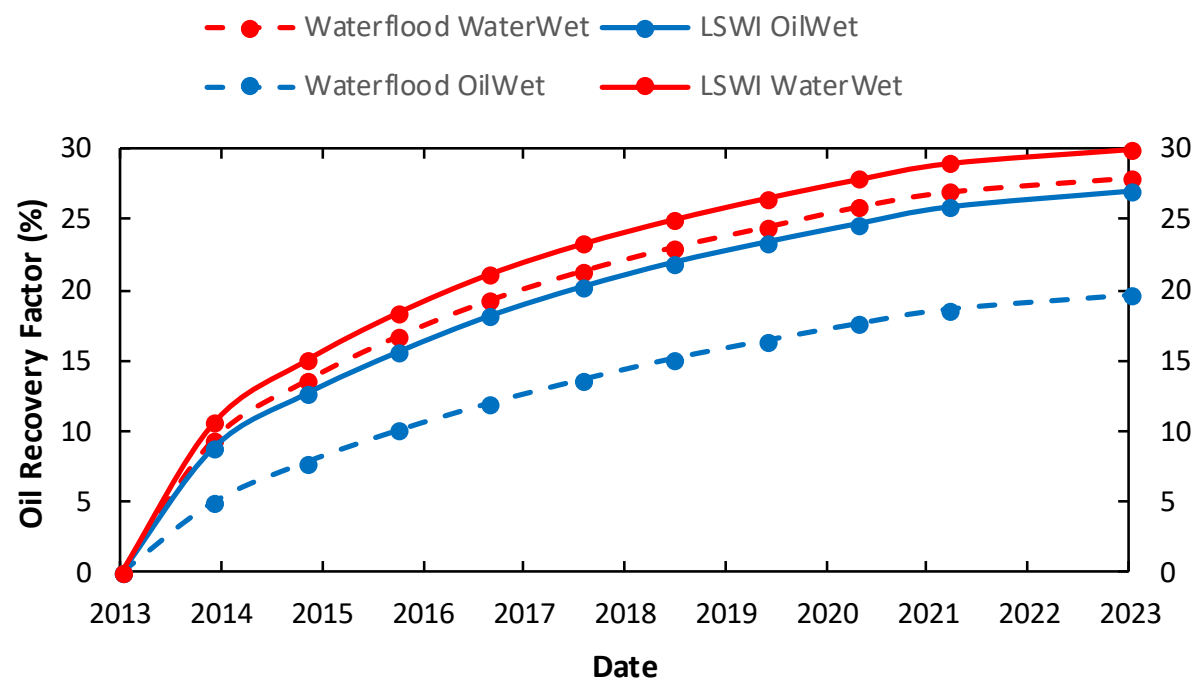

Figure 2. Incremental oil recovery by LSWI in preferential oil wet and water wet reservoirs (Reproduced from Dang, Nghiem, Nguyen, Chen, et al., (2015)).

Summary from several coreflooding experiments (Akhmetgareev \& Khisamov, 2015; Rivet et al., 2010; Shehata et al., 2016) shows that WF and LSWI have different relative permeability curve parameters. Thus, the wettability alteration caused by LSWI can be observed in the difference between the parameters of relative permeability curve. Table 3 shows the parameters of the relative permeability curve.

The Gross Split scheme introduced on Regulation No. 8 of 2017 (as amended by Regulation No.52 of 2017) splits gross revenues derived from hydrocarbon production between the Government and Contractors. Contractors must bear all capital and operating costs subject to such costs being tax deductible if commercial reserves are discovered and production generates taxable revenue (Roach $\&$ Dunstan, 2018).

The Government believes that the Gross Split scheme should incentivize exploration and exploitation activities due to the spending and operational "freedom" it conveys to Contractors. The scheme should allow Contractors to focus on cost efficiency and reducing the bureaucratic process for expenditures approval. The scheme is also still allowing the Government to be involved in approving key phases of upstream business developments (PriceWaterCooper, 2018).

The Contractors split are the sum of the base split percentages, variable components, and progressive components. Table 4 specifies the base split percentages and Table 5 specifies the split percentages of all the variable and progressive components.

Tax rules for the Gross Split is explained in Regulation No. 53 of 2017. The general fiscal framework appears broadly in line with that for PSC although further regulations will be required before Contractors can draw more definitive conclusions (Peraturan Pemerintah Nomor 53 Tahun 2017 Tentang Perlakuan Perpajakan Pada Kegiatan Usaha Hulu Minyak dan Gas Bumi dengan Kontrak Bagi Hasil Gross Split, 2017).

PSCs have evolved through five "generations" with the main variations on the production sharing split. Since 2008, the fifth generation of PSC with cost recovery mechanism has been introduced (PriceWaterCooper, 2018). Table 6 shows the summary of the PSC scheme split calculation. To ensure a constant after-tax share for Contractors, the before-tax share has adjusted over the years as Indonesia's general income tax has been lowered. Table 7 summarized the calculations for before-tax share, after-tax share, and income tax. Figure 3 shows the comparison between Gross Split and PSC mechanism.

In terms of economic evaluation, LSWI project can utilize facilities of conventional WF, the major difference comes from water desalination cost. There are obvious expenditures for LSWI desalination facilities that depend on several important factors such as salinity of water source, targeted salinity of injected water, field location, project scale, energy cost, and oil price.

The desalination cost for LSWI is not widely reported, however there are several methods for desalination technology, one of them is Electrodialysis Reversal (EDR). The EDR operates by mass flux of ions through 
membranes, and therefore a greater change in salinity increases mass flux, which increases both membrane area, or the capital expenditure (CAPEX), and the operating expenditure (OPEX) (Sparrow et al., 2018).

Table 3. Summary of LSWI coreflood experiments.

\begin{tabular}{|c|c|c|c|c|c|c|c|c|c|c|c|}
\hline \multicolumn{2}{|c|}{ Injected Brine } & \multicolumn{2}{|l|}{$\mathrm{S}_{\text {or }}$} & \multirow{2}{*}{$\begin{array}{l}\text { Sor } \\
\text { Ratio }\end{array}$} & \multirow{2}{*}{$\begin{array}{l}\mathrm{K}_{\mathrm{rw}} \\
\mathrm{WF}\end{array}$} & \multirow[b]{2}{*}{ LSWI } & \multirow{2}{*}{$\begin{array}{l}\mathrm{K}_{\mathrm{rw}} \\
\text { Ratio }\end{array}$} & \multicolumn{2}{|l|}{$\mathrm{K}_{\mathrm{ro}}$} & \multicolumn{2}{|c|}{ Oil Recovery (\%) } \\
\hline WF & LSWI & WF & LSWI & & & & & WF & LSWI & WF & LSWI \\
\hline $\begin{array}{l}174,156 \\
\text { ppm }\end{array}$ & $\begin{array}{l}\mathrm{NaCl} \\
5,000 \\
\text { ppm }\end{array}$ & 0.38 & 0.3 & 0.789 & 0.177 & 0.162 & 0.915 & 0.261 & 0.312 & 34.8 & 48.4 \\
\hline $\begin{array}{l}174,156 \\
\text { ppm }\end{array}$ & $\begin{array}{l}\mathrm{NaCl} \\
5,000 \\
\mathrm{ppm}\end{array}$ & 0.6 & 0.43 & 0.717 & 0.215 & 0.207 & 0.963 & 0.347 & 0.3 & 21.9 & 43.8 \\
\hline $\begin{array}{l}\mathrm{NaCl} \\
24,190 \\
\text { ppm, } \\
\mathrm{CaCl}_{2} \\
6,180 \\
\mathrm{ppm}, \\
\mathrm{Na}_{2} \mathrm{~S}_{2} \mathrm{O}_{4} \\
140 \mathrm{ppm}\end{array}$ & $\begin{array}{l}\mathrm{NaCl} 790 \\
\mathrm{ppm}, \\
\mathrm{CaCl}_{2} 210 \\
\mathrm{ppm}, \\
\mathrm{Na}_{2} \mathrm{~S}_{2} \mathrm{O}_{4} \\
140 \mathrm{ppm}\end{array}$ & 0.367 & 0.318 & 0.866 & 0.052 & 0.043 & 0.827 & 0.34 & 0.29 & 50.2 & 57.5 \\
\hline $\begin{array}{l}\mathrm{NaCl} \\
24,190 \\
\text { ppm, } \\
\mathrm{CaCl}_{2} \\
6,180 \\
\text { ppm, } \\
\mathrm{Na}_{2} \mathrm{~S}_{2} \mathrm{O}_{4} \\
140 \mathrm{ppm}\end{array}$ & $\begin{array}{l}\mathrm{NaCl} \\
1,000 \\
\text { ppm, } \\
\mathrm{Na}_{2} \mathrm{~S}_{2} \mathrm{O}_{4} \\
140 \text { ppm }\end{array}$ & 0.367 & 0.376 & 1.025 & 0.052 & 0.051 & 0.981 & 0.34 & 0.29 & 50.2 & 50 \\
\hline $\begin{array}{l}\mathrm{NaCl} \\
24,190 \\
\text { ppm, } \\
\mathrm{CaCl}_{2} \\
6,180 \\
\mathrm{ppm}, \\
\mathrm{Na}_{2} \mathrm{~S}_{2} \mathrm{O}_{4} \\
140 \mathrm{ppm}\end{array}$ & $\begin{array}{l}\mathrm{CaCl}_{2} \\
1,000 \\
\text { ppm, } \\
\mathrm{Na}_{2} \mathrm{~S}_{2} \mathrm{O}_{4} \\
140 \text { ppm }\end{array}$ & 0.367 & 0.381 & 1.038 & 0.052 & 0.059 & 1.135 & 0.34 & 0.35 & 50.2 & 48.7 \\
\hline $\begin{array}{l}\mathrm{NaCl} \\
124,717 \\
\mathrm{ppm} \\
\mathrm{MgCl}_{2} \\
28,704 \\
\mathrm{ppm}, \\
\mathrm{MgSO}_{4} \\
85.5 \mathrm{ppm}, \\
\mathrm{CaCl}_{2} \\
99,231 \\
\mathrm{ppm}\end{array}$ & $\begin{array}{l}\mathrm{NaCl} 20.1 \\
\text { ppm, } \\
\mathrm{MgCl}_{2} \\
28.1 \mathrm{ppm}, \\
\mathrm{MgSO}_{4} \\
137.8 \\
\mathrm{ppm}, \\
\mathrm{CaCl}_{2} \\
276.9 \\
\mathrm{ppm} \\
\mathrm{NaHCO}_{3} \\
385.5 \\
\mathrm{ppm}\end{array}$ & 0.58 & 0.56 & 0.966 & 0.043 & 0.021 & 0.488 & 0.99 & 0.99 & 36.8 & 39.1 \\
\hline $\begin{array}{l}\mathrm{NaCl} \\
124,717 \\
\mathrm{ppm} \\
\mathrm{MgCl}_{2} \\
28,704 \\
\mathrm{ppm}, \\
\mathrm{MgSO}_{4} \\
85.5 \mathrm{ppm} \\
\mathrm{CaCl}_{2} \\
99,231 \\
\mathrm{ppm}\end{array}$ & $\begin{array}{l}\mathrm{NaCl} 20.1 \\
\text { ppm, } \\
\mathrm{MgCl}_{2} \\
28.1 \mathrm{ppm}, \\
\mathrm{MgSO}_{4} \\
137.8 \\
\mathrm{ppm}, \\
\mathrm{CaCl}_{2} \\
276.9 \\
\mathrm{ppm} \\
\mathrm{NaHCO}_{3} \\
385.5 \\
\text { ppm }\end{array}$ & 0.395 & 0.27 & 0.684 & 0.054 & 0.051 & 0.944 & 0.95 & 0.95 & 53.4 & 68.2 \\
\hline
\end{tabular}


Economic Evaluation of Fiscal Regime on EOR Implementation in Indonesia: a Case Study of Low Salinity Water Injection

on Field X

(Adityawarman, F. A. Aziz, P. A. Aziz, P. Yusgiantoro, S. Chandra)

Table 4. Base split percentage (Permen ESDM No 08 Tahun 2017 Tentang Kontrak Bagi Hasil Gross Split, 2017).

\begin{tabular}{lll}
\hline Hydrocarbon & Contractor & Government \\
\hline Oil & $43 \%$ & $57 \%$ \\
Gas & $48 \%$ & $52 \%$ \\
\hline
\end{tabular}

Table 5. Variable and progressive components (Reproduced from Roach \& Dunstan (2018)).

\begin{tabular}{|c|c|c|}
\hline Components & Entitlement split percentage charge & Remarks \\
\hline Status of field & $+5 \%(\mathrm{POD} I),+3 \%(\mathrm{POD} I \mathrm{I})$ & $\begin{array}{l}\text { In the event production in soon-to-be } \\
\text { terminated working area continues without } \\
\text { POD, there is a } 0 \% \text { revision to the entitlement } \\
\text { split }\end{array}$ \\
\hline Location of field & $0 \%$ (Onshore), 8 to $16 \%$ (Offshore) & $\begin{array}{l}\text { Offshore percentages depend on sea depth, as } \\
\text { follows: } \\
\text { - Below/equal to } 20 \text { meters: }+8 \% \\
\text { - Above } 20 \text { meters, but below/equal to } 50 \text { : } \\
+10 \% \\
\text { - Above } 50 \text { meters, but below/equal to } 150 \text { : } \\
+12 \% \\
\text { - Above } 150 \text { meters, but below/equal to } 1000 \text { : } \\
+14 \% \\
\text { - Above } 1000 \text { meters: }+16 \%\end{array}$ \\
\hline Depth of reservoir & $1 \%$ & If vertical depth of wells exceeds 2500 meters \\
\hline $\begin{array}{l}\text { Availability of } \\
\text { supporting } \\
\text { infrastructure }\end{array}$ & $\begin{array}{l}0 \% \text { (Well developed), } 2 \% \text { (New Frontiers } \\
\text { Offshore), } 4 \% \text { (New Frontiers Onshore) }\end{array}$ & $\begin{array}{l}\text { Increased percentage only awarded where } \\
\text { supporting infrastructure (such as roads) is not } \\
\text { available }\end{array}$ \\
\hline \multirow[t]{4}{*}{ Reservoir type } & $0 \%$ (Conventional), $16 \%$ (Unconventional) & $\begin{array}{l}\text { Increased percentage for coal-bed methane and } \\
\text { shale reservoirs }\end{array}$ \\
\hline & & $\begin{array}{l}\text { Increased percentage dependent on percentage } \\
\text { of } \mathrm{CO} 2 \text { content above } 5 \% \text {, as follows: }\end{array}$ \\
\hline & & - Below 5\%: $+0 \%$ \\
\hline & & - Above/equal to $5 \%$, but below $10 \%:+0.5 \%$ \\
\hline \multirow[t]{5}{*}{$\mathrm{CO}_{2}$ content } & 0 to $4 \%$ & $\begin{array}{l}\text { - Above/equal to } 10 \% \text {, but below } 20 \%:+1 \% \\
\text { - Above/equal to } 20 \% \text {, but below } 40 \% \text { : } \\
+1.5 \%\end{array}$ \\
\hline & & - Above/equal to $40 \%$, but below $60 \%:+2 \%$ \\
\hline & & - Above/equal to $60 \%$ : $+4 \%$ \\
\hline & & $\begin{array}{l}\text { Increased percentage dependent on } \mathrm{H} 2 \mathrm{~S} \\
\text { content above } 100 \mathrm{ppm} \text {, as follows: }\end{array}$ \\
\hline & & - Below 100ppm: $+0 \%$ \\
\hline \multirow[t]{2}{*}{$\mathrm{H}_{2} \mathrm{~S}$ content } & 0 to $5 \%$ & $\begin{array}{l}- \text { Above/equal to } 100 \mathrm{ppm} \text {, but below } 1000 \text { : } \\
+1 \%\end{array}$ \\
\hline & & $\begin{array}{l}- \text { Above/equal to } 1000 \mathrm{ppm} \text {, but below } 2000 \text { : } \\
+2 \%\end{array}$ \\
\hline
\end{tabular}


Oil specific gravity $\quad 1 \%$

Local content $\quad 0$ to $4 \%$

Stage of production

0 to $10 \%$

Progressive
component

Oil price

Formulaic-based approach

Gas price

Cumulative production
0 to $10 \%$
- Above/equal to 2000ppm, but below 3000:

$+3 \%$

- Above/equal to 3000ppm, but below 4000:

$+4 \%$

- Above/equal to $4000 \mathrm{ppm}:+5 \%$

Increased percentage if specific gravity above 25 API

Increased percentage dependent on level of local content usage based on existing regulations, as follows:

- Below 30\%: $+0 \%$

- Above/equal to $30 \%$, but below 50: $+2 \%$

- Above/equal to $50 \%$, but below $70:+3 \%$

- Above/equal to $70 \%$, but below 100: +4\%

Increased percentage dependent on whether primary, secondary or tertiary production, the latter including enhanced oil recovery, as follows:

- Primary: $+0 \%$

- Secondary: $+6 \%$

- Tertiary: $+10 \%$

(85-ICP) $\times 0.25$ ICP is the Indonesian Crude Oil Price determined by the ESDM in accordance with applicable laws and regulations

- Price below 7 US\$/MMBTU: ( 7 - Gas

Price) x 2.5

- Price above/equal to 7 to 10 US\$/MMBTU: $0 \%$

- Price above 10 US\$MMBTU: (10 - Gas

Price) $\mathrm{x} 2.5$

- Below 30: $+10 \%$

- Above/equal to 30, but below 60: $+9 \%$

- Above/equal to 60, but below 90: $+8 \%$

- Above/equal to 90, but below 125: $+6 \%$

- Above/equal to 125 , but below 175: $+4 \%$

- Above 175: $+0 \%$

Table 6. All generation PSC scheme split calculation (Reproduced from PriceWaterCooper (2018)).

\begin{tabular}{llllll}
\hline & $\begin{array}{l}\text { New Contracts } \\
(\%)\end{array}$ & $\begin{array}{l}1995 \text { Eastern } \\
\text { Provinces PSC } \\
(\%)\end{array}$ & 1995 PSC (\%) & $\begin{array}{l}1985-1994 \\
\text { PSC }(\%)\end{array}$ & Old PSC (\%) \\
\hline Tax Rate & 40 & 44 & 44 & 48 & 56
\end{tabular}


Economic Evaluation of Fiscal Regime on EOR Implementation in Indonesia: a Case Study of Low Salinity Water Injection

on Field X

(Adityawarman, F. A. Aziz, P. A. Aziz, P. Yusgiantoro, S. Chandra)

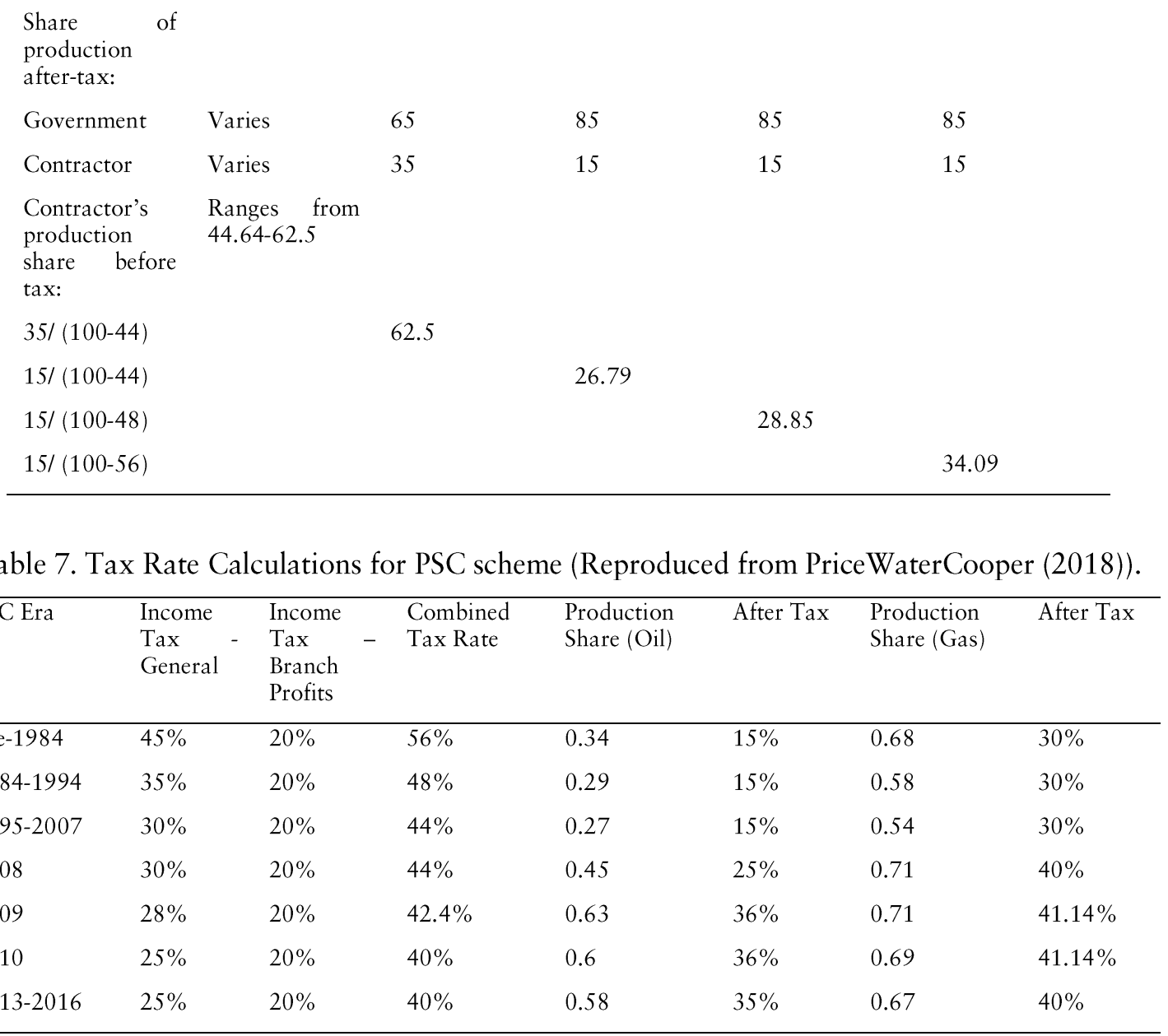

Therefore, desalination cost by using EDR is a function of the amount of water treated and salinity difference between source water and injected water. This study is aimed to present a new viewpoint on how the LSWI would be economical enough to be implemented in gross split fiscal scheme, using field X data as a benchmark.

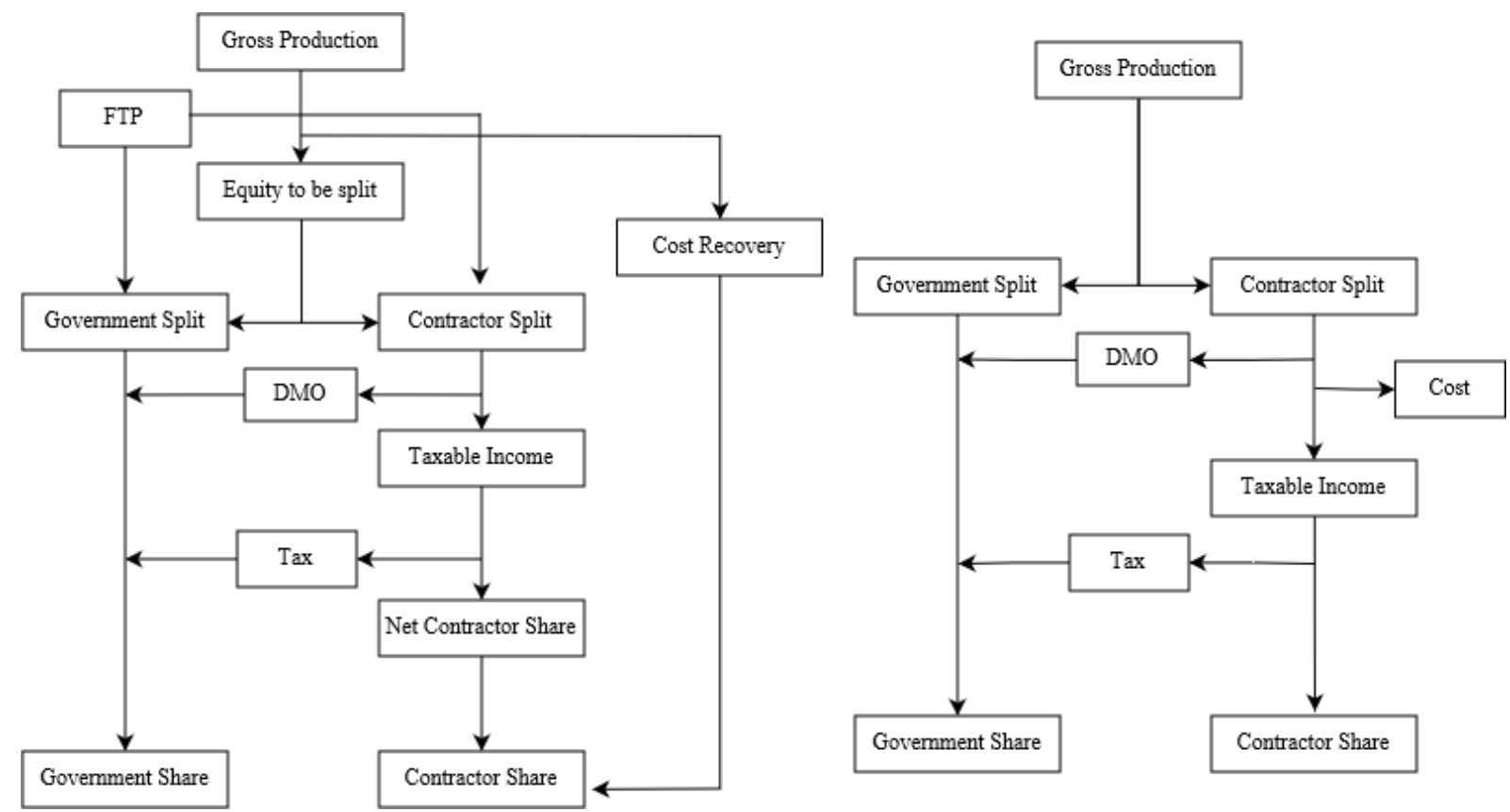

Figure 3. Comparison of PSC and Gross Split Mechanism (Reproduced from SKK Migas, 2017). 


\section{METHODOLOGY}

Figure 4 shows the flowchart for this study to be completed. First, literature study is conducted to verify the background and the objectives of this study. The basic theory is also collected in this literature study. Next, four cases are made, the cases are the Base Case (business as usual), WF, LSWI 1, and LSWI 2. The cases will be simulated for 5 years using commercial reservoir simulator. The case project's economy then will be evaluated using PSC and Gross Split scheme to observe the effect of different fiscal regime on LSWI implementation on Field X. Sensitivity analysis will also be conducted to observe which parameter affects the NPV most. The last step is conclusions will be made from the economic evaluation results and sensitivity analysis to see whether Gross Split is more EOR friendly than PSC.
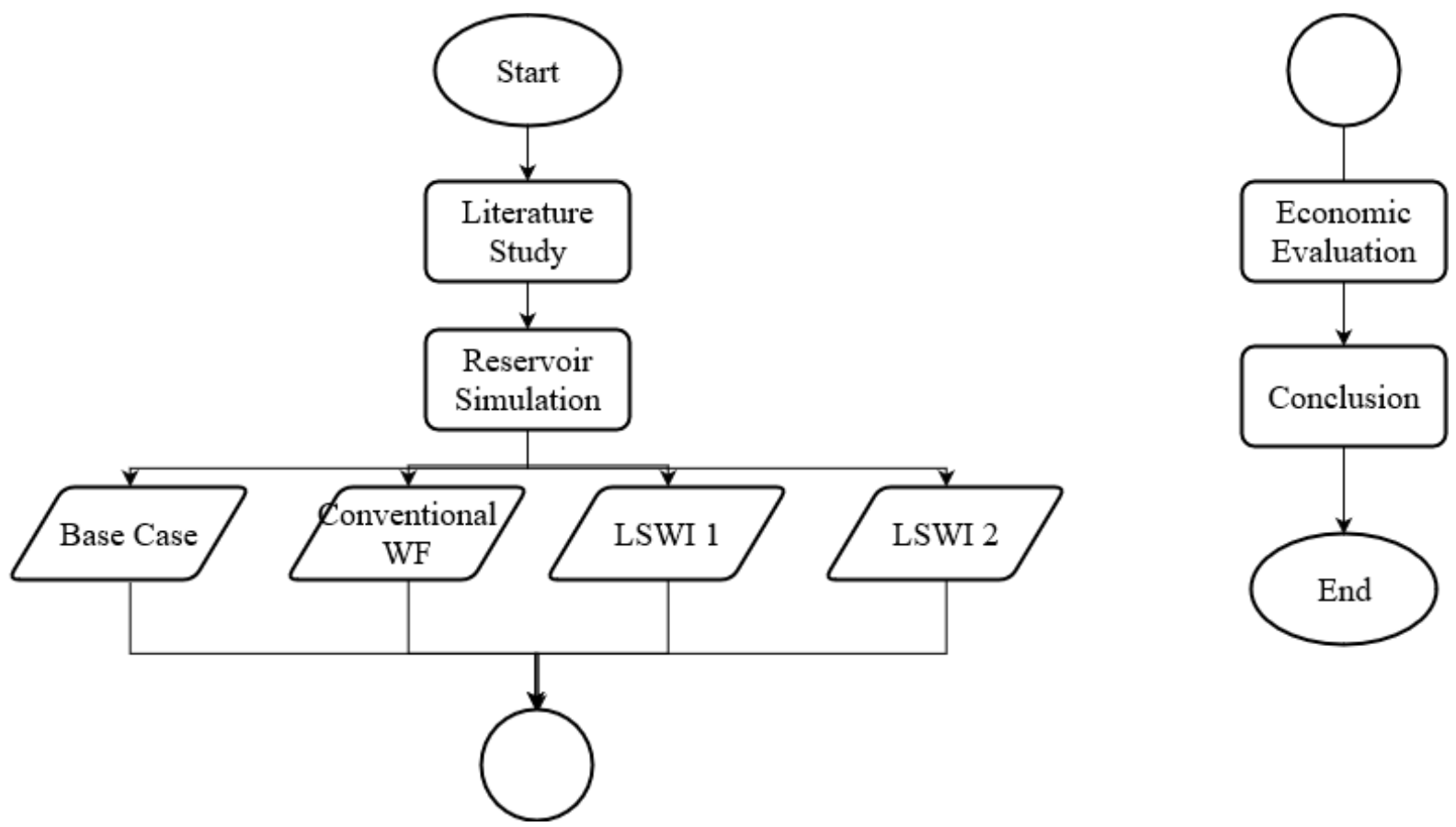

\section{Case Study}

The field that is used in this study is Field X. The reservoir in Field X is identified as a sandstone reservoir. Figure 5 and Figure 6 show the inverted 4-spot injection pattern at Field X that is evaluated in this study. In the simulator, a static model dimension is defined by 1450 total active blocks. The water saturation and permeability distribution of reservoir model are shown respectively in Figure 7 . The average reservoir pressure is $1200 \mathrm{psia}$ and the average temperature is $151.1^{\circ} \mathrm{F}$, reservoir depth is $2000 \mathrm{ft}$.

There are 4 cases that will be simulated. The first case, Base Case, is natural depletion production so the Well-4 as the injection well is shut off. The second case, WF, is waterflooding project with the assumption that the injected water salinity is $25,000 \mathrm{ppm}$. The third case, LSWI 1 , is LSWI project with the injected water salinity is set at $1000 \mathrm{ppm}$. The last case, LSWI 2, is also LSWI project with the injected water salinity is set at $2000 \mathrm{ppm}$. 


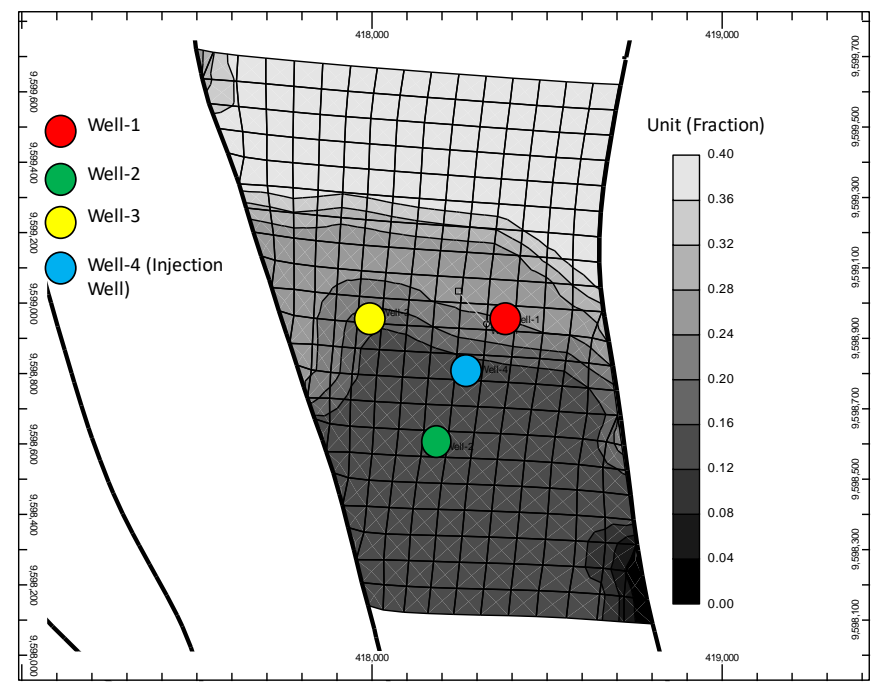

Figure 5. Inverted 4-spot injection pattern.

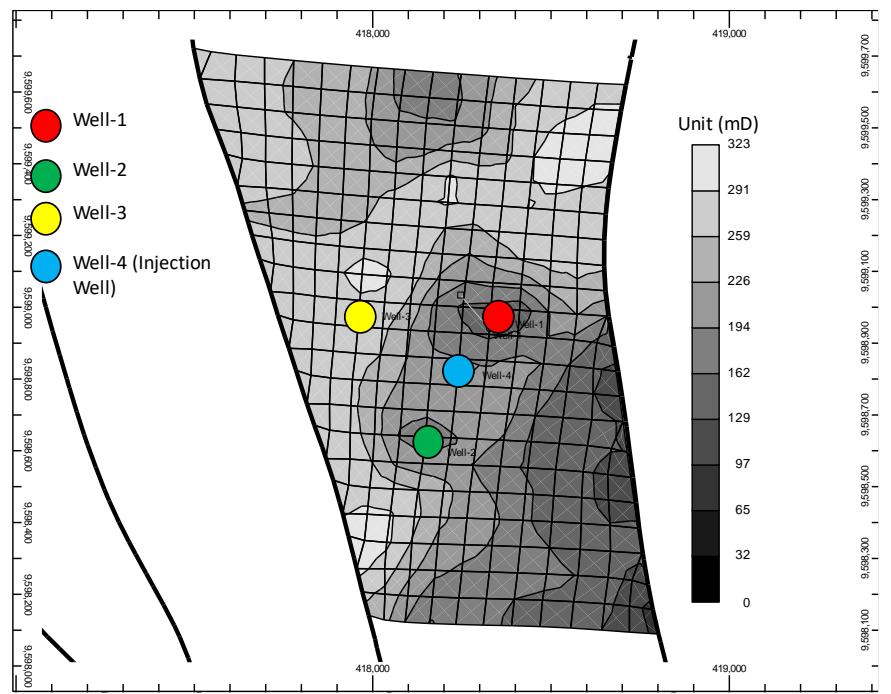

Figure 6. Water saturation distribution on reservoir model.

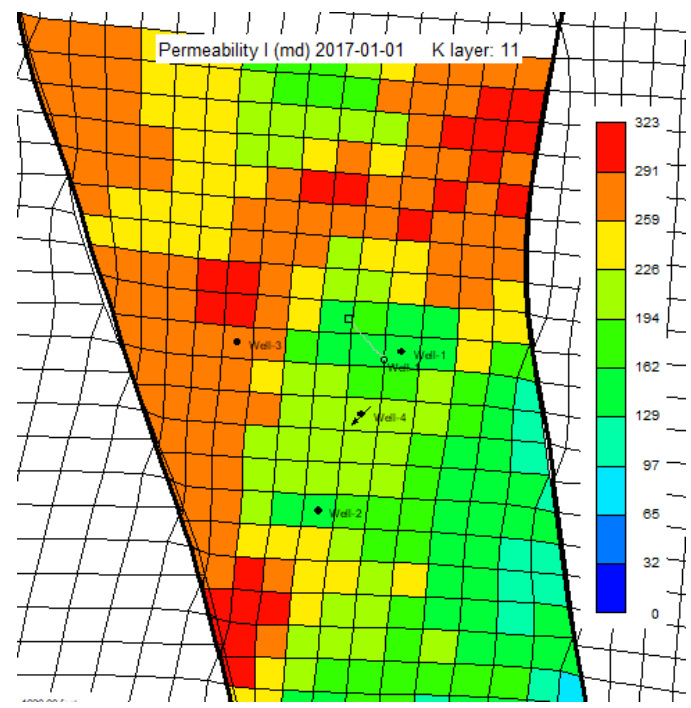

Figure 7. Permeability distribution on reservoir model.

The LSWI modelling is done using LSWI Process Wizard in the commercial simulator. Table 8 shows the parameter for LSWI modelling that is applied in all the LSWI cases. The effect of wettability alteration is 
modeled by shifting the relative permeability curves. The author uses the result from coreflooding experiment done by Shehata et al. (2016) to alter $S_{\text {or }}$ and $\mathrm{K}_{\mathrm{rw}}$ for LSWI implementation because in the experiment the injected water is $\mathrm{NaCl}$ and on LSWI cases on Field $\mathrm{X}$ also using $\mathrm{NaCl}$, therefore on Field $\mathrm{X}$ the author assume $\mathrm{S}_{\mathrm{or}}$ ratio is 0.717 and the $\mathrm{K}_{\mathrm{rw}}$ ratio is 0.963 . Figure 8 shows the relative permeability shifts for this study. The commercial simulator incorporates three dominant mechanisms in modeling LSWI namely using the multi-component ion exchange mechanism, aqueous reaction, and mineral dissolution \& precipitation (Pouryousefy et al., 2016). Other mechanisms such as wetting \& non-wetting phase interpolation parameters (Hakiki et al., 2015), changes in capillary pressure (Hakiki et al., 2017), surface roughening (Marhaendrajana et al., 2018) is not considered in this problem since it is not included in the process wizard.

Table 8. Input parameter for LSWI modelling.

\begin{tabular}{ll}
\hline Properties & Value/Notes \\
\hline Low Salinity Modelling Method & $\begin{array}{l}\text { Ion Exchange Relative } \\
\text { Interpolation }\end{array}$ \\
Ion Exchange Component & $\mathrm{Na}-\mathrm{X}$ \\
Range of Rel. Perm. Interpolation in Equivalent Fraction & \\
of Na-X & $0.42-0.15$ \\
Number of Rel. Perm. Sets & 2 \\
Sorw Reduction for Set 2 & 0.717 \\
Krw Reduction for Set 2 & 0.963 \\
Change Kro curvature when Sor $<0.1$ & Yes \\
Calculate effective Sor & If Kro $<0.001$ \\
Corey Number when Sor $<0.1$ & 2 \\
Ion Exchange Reaction & $\mathrm{Na}++0.5 \mathrm{Ca}-\mathrm{X} 2=0.5 \mathrm{Ca} 2++\mathrm{Na}-\mathrm{X}$ \\
Cation Exchange Capacity for All Blocks & $50(\mathrm{~mol} / \mathrm{m} 3 \mathrm{x}$ charge of ion $)$ \\
pH of Initial Water & 5.3552 \\
Ca2+ Initial Concentration & $680.001 \mathrm{ppm}$ \\
Na+ Initial Concentration & $8427.99 \mathrm{ppm}$ \\
Cl- Initial Concentration & $14555 \mathrm{ppm}$ \\
Calcite Initial Volume Fraction & 0.07 \\
\hline
\end{tabular}

All the cases will be simulated for 5 years, starting from January $1^{\text {st }}, 2017$ until January $1^{\text {st }}, 2022$. During production, the injection will also be started from the beginning of the simulation and will be run for 5 years also. Liquid group production rate of the pattern is limited to $150 \mathrm{bbl} / \mathrm{day}$. The injection rate is fixed at $100 \mathrm{bbl} / \mathrm{day}$. The minimum bottom hole pressure constraint for each production well is set at $400 \mathrm{psia}$ and maximum bottom hole pressure for Well-4 is set at 2000 psi.

Economic evaluation will be based on cash flow calculation of each cases and the cash flow will be calculated using two schemes, the PSC and Gross Split scheme. The economic indicator that will be evaluated is the NPV. The basis of cash flow calculation is investments and revenues. In this study, the investments consist of CAPEX and OPEX, and the revenues are generated from oil production from Field $\mathrm{X}$.

Base Case has no additional investment, so both the CAPEX and OPEX are zero in the cash flow calculation. WF case have additional investments in waterflooding facilities. LSWI 1 and LSWI 2 case also have additional investments in water desalination facilities and waterflooding facilities. As mentioned before, water desalination facilities cost is a function of the amount of water treated and the removed salinity between source water and injected water. Figure 9 and Figure 10 show the desalination cost function to salinity removed. The EDR is assumed to have $90 \%$ efficiency, so the water treated rate is 110 $\mathrm{bbl} / \mathrm{day}$ for the targeted water injected rate of $100 \mathrm{bbl} / \mathrm{day}$. Table 9 summarizes the investments for WF, LSWI 1, and LSWI 2 cases. 


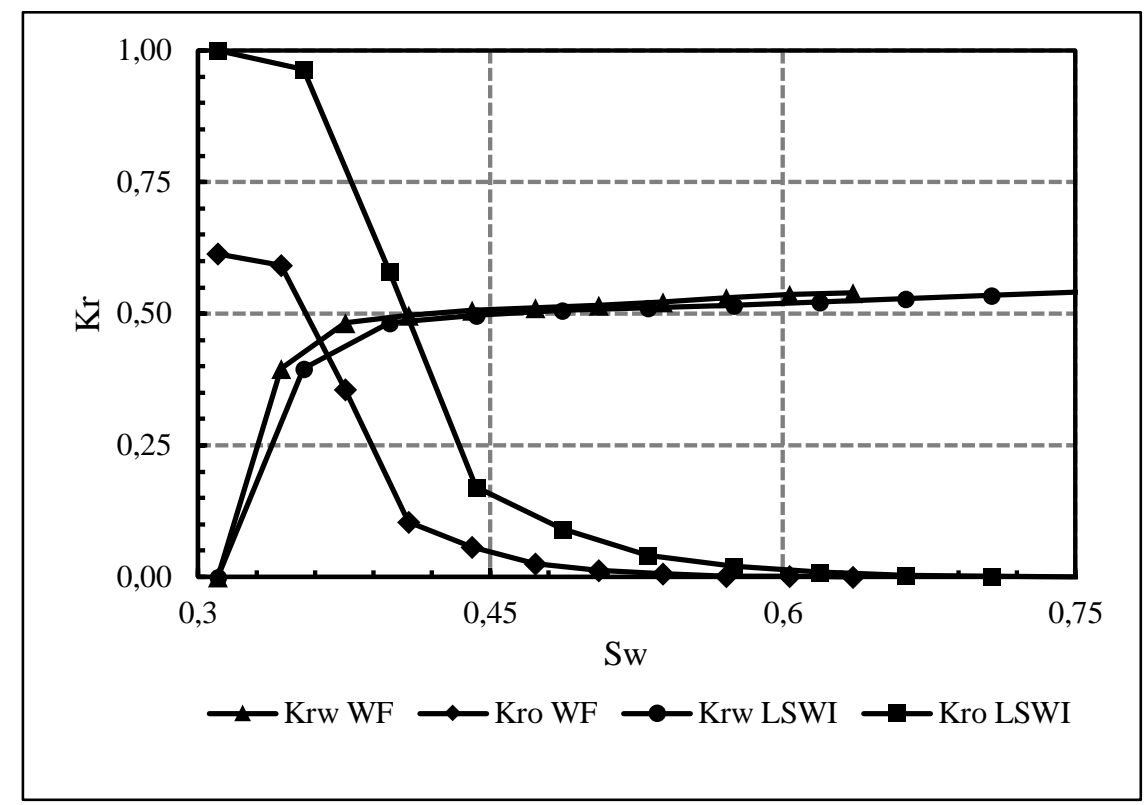

Figure 8. Relative permeability curve.

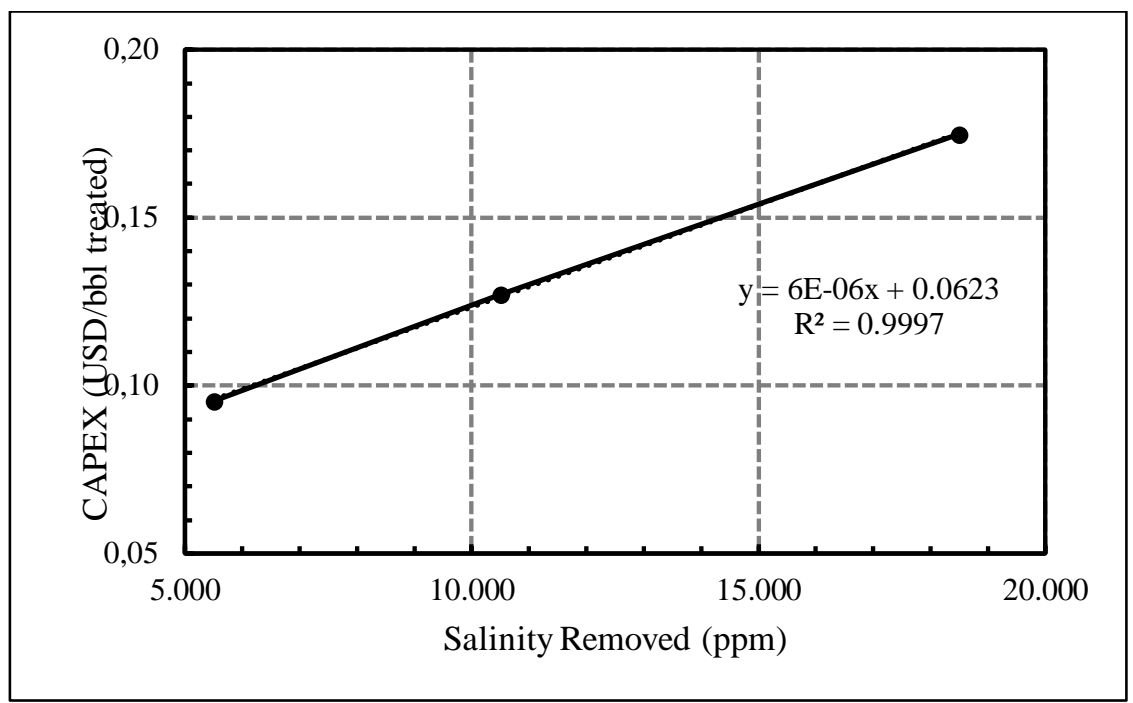

Figure 9. CAPEX desalination cost.

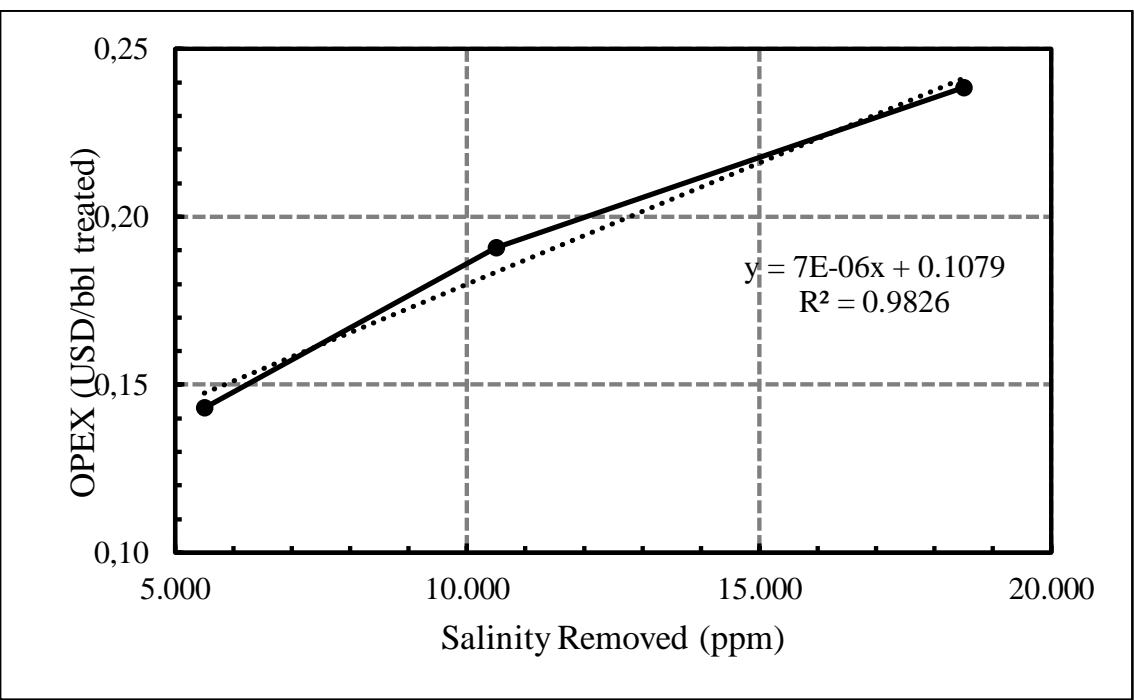

Figure 10. OPEX desalination cost. 
Table 9. Investment cost.

\begin{tabular}{lll}
\hline Case & CAPEX (thousand USD) & OPEX (thousand USD/year) \\
\hline WF & 132.50 & 4.00 \\
LSWI 1 & 173.94 & 11.08 \\
LSWI 2 & 172.73 & 10.80 \\
\hline
\end{tabular}

Table 10. Economic analysis assumptions.

\begin{tabular}{lll}
\hline Parameter & Unit & Value \\
\hline Oil Price & USD/bbl & 60 \\
Tax Rate & $\%$ & 40 \\
DMO & $\%$ & 25 \\
DMO Fee & $\%$ & 100 \\
Discount Rate & $\%$ & 10 \\
FTP (PSC) & $\%$ & 20 \\
After Tax Split (PSC) & $\%$ & 35 \\
Depreciation Rate & $\%$ & 25 \\
Depreciation Duration & years & 5 \\
\hline
\end{tabular}

Table 10 summarizes the general assumptions that is used in this economic evaluation. For Gross Split calculation, there are variables that add the split for Contractor, so Table 11 shows the Gross Split parameter assumptions used in this study.

Sensitivity analysis is conducted to determine which of the following parameters: CAPEX, OPEX, oil production, and oil price, that have the most effect on NPV. The sensitivity analysis is conducted by changing the parameter value with the changing factor of $30 \%$, so the value of the parameters is ranging from $70 \%$ to $130 \%$.

Table 11. Gross Split parameter assumptions.

\begin{tabular}{lll}
\hline Base Case & & \\
\hline Variable & Status & Added Split \\
\hline Status of Field & No POD & $0 \%$ \\
Location & Onshore & $0 \%$ \\
Depth & $<2500 \mathrm{~m}$ & $0 \%$ \\
Infrastructure & Well Developed & $0 \%$ \\
Reservoir Type & Sandstone & $0 \%$ \\
$\mathrm{CO}_{2}$ Content & $20 \%$ & $1.5 \%$ \\
$\mathrm{H}_{2} \mathrm{~S}$ Content & 5 ppm & $0 \%$ \\
SG & $30{ }^{\circ} \mathrm{API}$ & $0 \%$ \\
Local Content & $60 \%$ & $3 \%$ \\
Production Stage & Primary & $0 \%$ \\
Oil Price & 60 USD/bbl & $6.25 \%$ \\
Cumulative Production & $<30 \mathrm{MMBOE}$ & $10 \%$ \\
\hline WF & & \\
\hline Variable & Status & Added Split \\
\hline Status of Field & POD II & $3 \%$ \\
Location & Onshore & $0 \%$ \\
Depth & $<2500 \mathrm{~m}$ & $0 \%$ \\
Infrastructure & Well Developed & $0 \%$ \\
\hline
\end{tabular}


Economic Evaluation of Fiscal Regime on EOR Implementation in Indonesia: a Case Study of Low Salinity Water Injection

on Field X

(Adityawarman, F. A. Aziz, P. A. Aziz, P. Yusgiantoro, S. Chandra)

\begin{tabular}{|c|c|c|}
\hline Reservoir Type & Sandstone & $0 \%$ \\
\hline $\mathrm{CO}_{2}$ Content & $20 \%$ & $1.5 \%$ \\
\hline $\mathrm{H}_{2} \mathrm{~S}$ Content & $5 \mathrm{ppm}$ & $0 \%$ \\
\hline SG & $30^{\circ} \mathrm{API}$ & $0 \%$ \\
\hline Local Content & $60 \%$ & $3 \%$ \\
\hline Production Stage & Secondary & $6 \%$ \\
\hline Oil Price & $60 \mathrm{USD} / \mathrm{bbl}$ & $6.25 \%$ \\
\hline Cumulative Production & $<30 \mathrm{MMBOE}$ & $10 \%$ \\
\hline \multicolumn{3}{|l|}{ LSWI } \\
\hline Variable & Status & Added Split \\
\hline Status of Field & POD II & $3 \%$ \\
\hline Location & Onshore & $0 \%$ \\
\hline Depth & $<2500 \mathrm{~m}$ & $0 \%$ \\
\hline Infrastructure & Well Developed & $0 \%$ \\
\hline Reservoir Type & Sandstone & $0 \%$ \\
\hline $\mathrm{CO}_{2}$ Content & $20 \%$ & $1.5 \%$ \\
\hline $\mathrm{H}_{2} \mathrm{~S}$ Content & $5 \mathrm{ppm}$ & $0 \%$ \\
\hline SG & $30^{\circ} \mathrm{API}$ & $0 \%$ \\
\hline Local Content & $60 \%$ & $3 \%$ \\
\hline Production Stage & EOR & $10 \%$ \\
\hline Oil Price & $60 \mathrm{USD} / \mathrm{bbl}$ & $6.25 \%$ \\
\hline Cumulative Production & $<30 \mathrm{MMBOE}$ & $10 \%$ \\
\hline \multicolumn{3}{|l|}{ Total Contractor Split } \\
\hline Base Case & WF & LSWI \\
\hline $63.75 \%$ & $72.75 \%$ & $76.75 \%$ \\
\hline
\end{tabular}

\section{RESULTS AND DISCUSSION}

The results of the simulation that will be used in this study is the oil production rate. Figure 11 shows the oil production rate for each case and Figure 12 shows the cumulative oil production, the authors observe that in all the cases, oil production rate drops rapidly after a year production. It can be concluded that low reservoir pressure and no aquifer support is the cause of this drop. All LSWI cases have higher cumulative production compared to conventional WF, therefore it can be implied that LSWI implementation on Field $\mathrm{X}$ is improving the oil recovery.

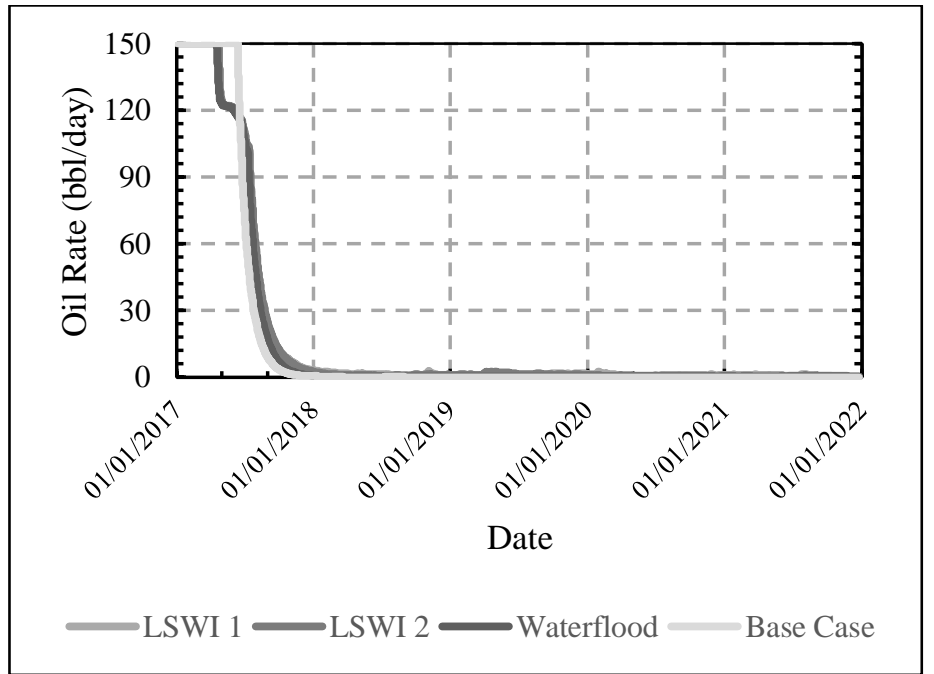

Figure 11. Oil production rate of Field X. 


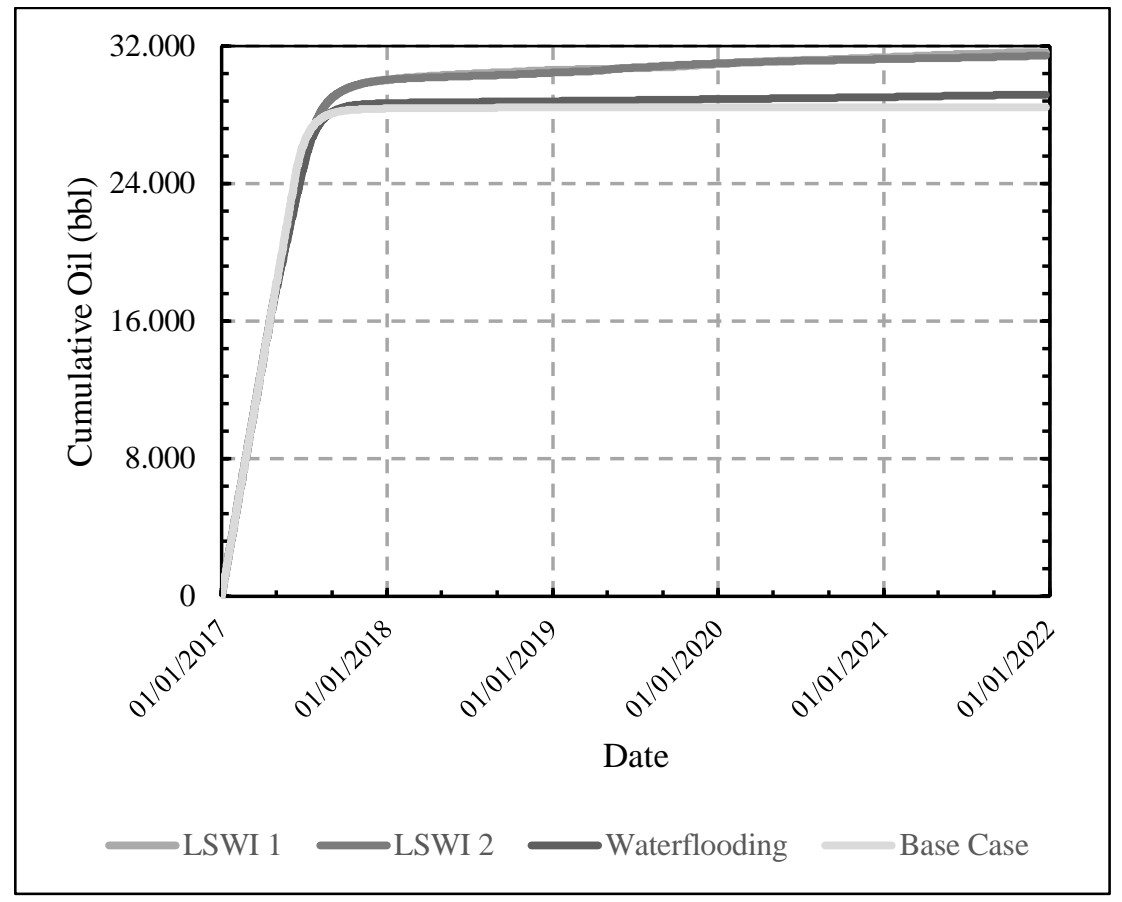

Figure 12. Cumulative oil production of Field X.

All the cases are evaluated using PSC and Gross Split scheme to calculate the NPV of each case. The NPV of Base Case, WF, LSWI 1, and LSWI 2 using PSC scheme are 493.6, 399.5, 410.3, and 405.5 thousand USD, respectively. The NPV of Base Case, WF, LSWI 1, and LSWI 2 using Gross Split scheme are 539.5, 513.0, 557.1, and 553.1 thousand USD, respectively. Table 12 shows the PSC calculation spreadsheet and Table 13 shows the Gross Split calculation spreadsheet for Base Case, the other cases also use the same calculation spreadsheet format and only changing some of the data for each case. Table 14 summarize the NPV for all the cases.

The authors observe from the NPV summary that in PSC scheme all the cases have smaller NPV than Base Case. It means that additional investments in all the cases using PSC scheme are not resulting in higher revenue for the Contractor, therefore causing the NPV to be smaller compared to the Base Case. On the other hand, in Gross Split scheme, LSWI 1 and LSWI 2 have greater NPV than Base Case and WF. It means that in Gross Split scheme, additional investments in LSWI cases resulting in higher NPV gain. LSWI 1 have the highest additional investment but it also has the highest NPV. Table 15 summarizes the percentage of NPV change for all the cases and the LSWI cases using Gross Split scheme are the only cases that have positive NPV percentage changes compared to its Base Case. The authors analyze the result to find the reasons why implementing different fiscal regime resulting in different NPV for the same case. First, the PSC scheme do not have clear incentives for developing Field X that is in the later stage of the field's life, as for the Gross Split scheme, additional split for implementing EOR turns out to be more profitable when the authors compare it with the PSC scheme. Second, the cost recovery mechanism of PSC will not be recovered fast enough because the oil production rate at Field $\mathrm{X}$ is already low from the second year. Cost recovery is paid by giving additional production share for the contractor, but if the gross revenue after First Tranche Petroleum (FTP) is lower compared to the contractor's cost to be recovered, then there will be unrecovered cost. From this analysis, the authors conclude that Gross Split scheme is more profitable for the Contractor than PSC scheme on EOR implementation, in this case LSWI implementation on Field X.

Revenue in Indonesia's oil and gas industry is a zero-sum game between Contractor and Government, which means that to increase the revenue for Contractor, Government's revenue must be lowered and vice versa. In all LSWI cases, the author observes that Government's revenue in PSC scheme is higher compared to Gross Split scheme. There are some reasons for the Government to lower their revenue on EOR implementation using Gross Split scheme in Indonesia, one of the reasons is many fields in Indonesia are mature fields, therefore EOR implementation is needed to increase the oil recovery. Additional split for tertiary recovery production stage in Gross Split scheme is designed to attract more Contractor to invest their money in Indonesia, especially on EOR implementation. More investments in EOR means more mature fields that have their oil recovery improved, it also means that Indonesia is getting the technological know-how in EOR implementations. 
Economic Evaluation of Fiscal Regime on EOR Implementation in Indonesia: a Case Study of Low Salinity Water Injection on Field X (Adityawarman, F. A. Aziz, P. A. Aziz, P. Yusgiantoro, S. Chandra)

Table 12. PSC calculation spreadsheet for base case.

\begin{tabular}{|c|c|c|c|c|c|c|c|}
\hline & Year & 0 & 1 & 2 & 3 & 4 & 5 \\
\hline Capital Cost & $\mathrm{M} \$$ & - & & & & & \\
\hline Capital Cost Depreciation & $\mathrm{M} \$$ & 0 & 0 & 0 & 0 & 0 & 0 \\
\hline Non-Capital Cost & $\mathrm{M} \$$ & 0 & 0 & 0 & 0 & 0 & 0 \\
\hline Cost to be Recovered & $\mathrm{M} \$$ & 0 & 0 & 0 & 0 & 0 & 0 \\
\hline Production & Mbbl & 0 & 28 & 0 & 0 & 0 & 0 \\
\hline Price & $\$ / b b l$ & 0 & 60 & 60 & 60 & 60 & 60 \\
\hline Gross Revenue & $\mathrm{M} \$$ & 0 & 1,702 & 3 & 1 & 1 & 0 \\
\hline Contr Split After Tax & $\%$ & 35 & 35 & 35 & 35 & 35 & 35 \\
\hline Effective Tax Rate & $\%$ & 40 & 40 & 40 & 40 & 40 & 40 \\
\hline Contractor Split (before tax) & $\%$ & 58 & 58 & 58 & 58 & 58 & 58 \\
\hline Govt Split (before tax) & $\%$ & 42 & 42 & 42 & 42 & 42 & 42 \\
\hline FTP & $\%$ & 20 & 20 & 20 & 20 & 20 & 20 \\
\hline FTP & $\mathrm{M} \$$ & 0 & 340 & 1 & 0 & 0 & 0 \\
\hline Gross Revenue after FTP & $\mathrm{M} \$$ & 0 & 1,362 & 3 & 1 & 1 & 0 \\
\hline Investment Credit & $\mathrm{M} \$$ & 0 & 0 & 0 & 0 & 0 & 0 \\
\hline Cost Recovery (Recoverable Cost) & $\mathrm{M} \$$ & 0 & 0 & 0 & 0 & 0 & 0 \\
\hline Unrecovered Cost & $\mathrm{M} \$$ & 0 & 0 & 0 & 0 & 0 & 0 \\
\hline ETS & $\mathrm{M} \$$ & 0 & 1,362 & 3 & 1 & 1 & 0 \\
\hline CONTRACTOR SHARE & $\mathrm{M} \$$ & 0 & 993 & 2 & 0 & 0 & 0 \\
\hline Contr FTP & $\mathrm{M} \$$ & 0 & 199 & 0 & 0 & 0 & 0 \\
\hline Contr Equity & $\mathrm{M} \$$ & 0 & 794 & 2 & 0 & 0 & 0 \\
\hline DMO, $25 \%$ & $\mathrm{M} \$$ & 0 & 248 & 0 & 0 & 0 & 0 \\
\hline DMO delivered & $\mathrm{M} \$$ & 0 & 248 & 0 & 0 & 0 & 0 \\
\hline DMO fee (25\%Price)) & $\mathrm{M} \$$ & 0 & 248 & 0 & 0 & 0 & 0 \\
\hline Taxable Share & $\mathrm{M} \$$ & 0 & 993 & 2 & 0 & 0 & 0 \\
\hline Govt.Tax & $\mathrm{M} \$$ & 0 & 397 & 1 & 0 & 0 & 0 \\
\hline Net Contractor Share & $\mathrm{M} \$$ & 0 & 596 & 1 & 0 & 0 & 0 \\
\hline Total Contractor Take & $\mathrm{M} \$$ & 0 & 596 & 1 & 0 & 0 & 0 \\
\hline Contr.Cash Flow & $\mathrm{M} \$$ & 0 & 596 & 1 & 0 & 0 & 0 \\
\hline Govt FTP & $\mathrm{M} \$$ & 0 & 142 & 0 & 0 & 0 & 0 \\
\hline Govt Equity & $\mathrm{M} \$$ & 0 & 567 & 1 & 0 & 0 & 0 \\
\hline Total Indonesia Take & $\mathrm{M} \$$ & 0 & 1,106 & 2 & 0 & 0 & 0 \\
\hline Contractor NPV @ 10 \% & $\mathrm{M} \$$ & 494 & & & & & \\
\hline
\end{tabular}


Table 13. Gross Split calculation spreadsheet for Base Case.

\begin{tabular}{|c|c|c|c|c|c|c|c|}
\hline & Year & 0 & 1 & 2 & 3 & 4 & 5 \\
\hline Capital Cost & $\mathrm{M} \$$ & - & - & - & - & - & - \\
\hline Capital Cost Depreciation & M\$ & 0 & 0 & 0 & 0 & 0 & 0 \\
\hline Non-Capital Cost & M\$ & 0 & 0 & 0 & 0 & 0 & 0 \\
\hline Production & Mbbl & 0 & 28 & 0 & 0 & 0 & 0 \\
\hline Price & $\$ / b b l$ & 60 & 60 & 60 & 60 & 60 & 60 \\
\hline Gross Revenue & M\$ & 0 & 1,702 & 3 & 1 & 1 & 0 \\
\hline Contr Split Percentage & $\%$ & 63.75 & 63.75 & 63.75 & 63.75 & 63.75 & 63.75 \\
\hline Effective Tax Rate & $\%$ & 40 & 40 & 40 & 40 & 40 & 40 \\
\hline CONTRACTOR SHARE & M\$ & 0 & 1,085 & 2 & 0 & 0 & 0 \\
\hline Contr Split & M\$ & 0 & 1,085 & 2 & 0 & 0 & 0 \\
\hline DMO, $25 \%$ & $\mathrm{M} \$$ & 0 & 271 & 1 & 0 & 0 & 0 \\
\hline DMO fee (25\%Price)) & $\mathrm{M} \$$ & 0 & 271 & 1 & 0 & 0 & 0 \\
\hline Taxable Share & M\$ & 0 & 1,085 & 2 & 0 & 0 & 0 \\
\hline Govt.Tax & M\$ & 0 & 434 & 1 & 0 & 0 & 0 \\
\hline Net Contractor Share & $\mathrm{M} \$$ & 0 & 651 & 1 & 0 & 0 & 0 \\
\hline Contr.Cash Flow & M\$ & 0 & 651 & 1 & 0 & 0 & 0 \\
\hline Govt Split & $\mathrm{M} \$$ & 0 & 617 & 1 & 0 & 0 & 0 \\
\hline Total Indonesia Take & M\$ & 0 & 1,051 & 2 & 0 & 0 & 0 \\
\hline Contractor NPV @ 10 \% & M\$ & 539 & & & & & \\
\hline
\end{tabular}

Table 14. NPV summary (thousand USD).

\begin{tabular}{lll}
\hline Case & PSC & Gross Split \\
\hline Base Case & 493.6 & 539.5 \\
WF & 399.5 & 513.0 \\
LSWI 1 & 410.3 & 557.1 \\
LSWI 2 & 405.5 & 553.1 \\
\hline
\end{tabular}

Table 15. NPV percentage change compared to Base Case.

\begin{tabular}{lll}
\hline Case & PSC & Gross Split \\
\hline Base Case & - & - \\
WF & $-19.07 \%$ & $-4.91 \%$ \\
LSWI 1 & $-16.83 \%$ & $3.28 \%$ \\
LSWI 2 & $-17.85 \%$ & $2.52 \%$ \\
\hline
\end{tabular}

Sensitivity analysis is conducted on LSWI 1 in both fiscal regimes to determine which parameter that will affect NPV the most. Figure 13 and Figure 14 show the spider diagram on LSWI 1 for PSC and Gross Split, respectively. From the PSC spider diagram, oil price and oil production are the parameters that will affect NPV the most. The explanation for this result is the gross revenue is generated by multiplying oil production and oil price, and when the authors compare the gross revenue with CAPEX and OPEX, the gross revenue is much larger than the CAPEX and OPEX. Therefore, in PSC scheme, small changes in either oil production or oil price will create bigger changes in the NPV. From the Gross Split spider diagram, oil production is the only parameter that most affecting the NPV. The reason why oil price is not 
having the same effect as in the PSC scheme is oil price is one of the progressive components that will cause split adjustment for the contractor, if the oil price is high then the contractor split will be lowered and vice versa. This mechanism is the reason that makes the changes in oil price in Gross Split scheme resulting in more stable NPV compared to PSC scheme.

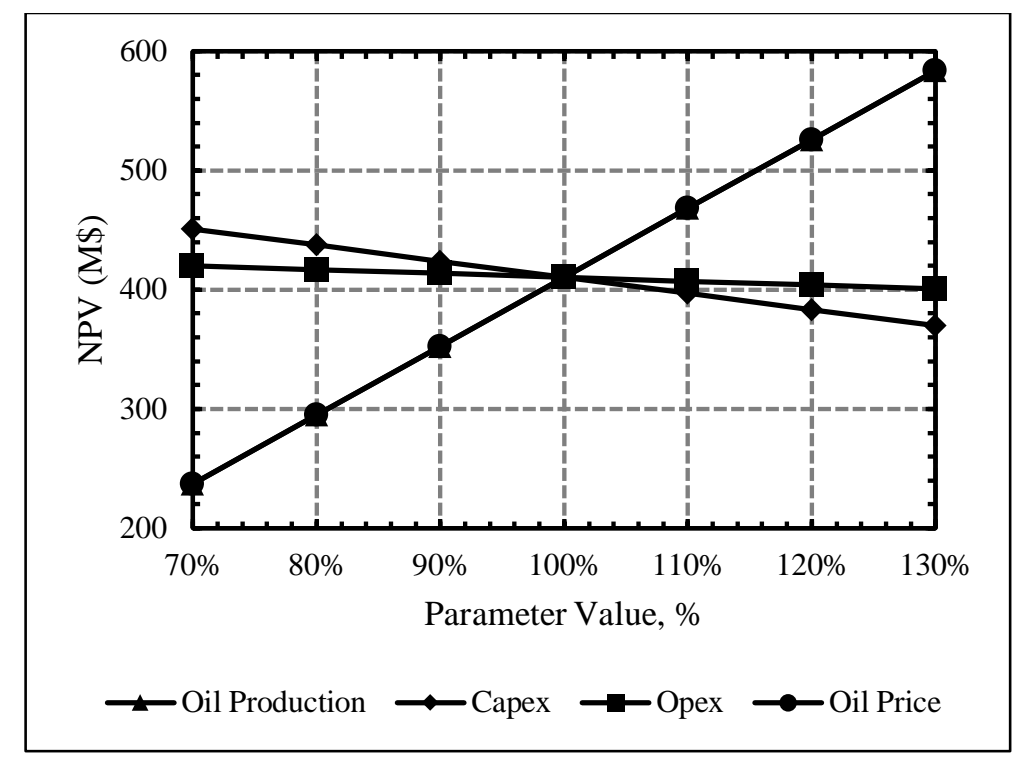

Figure 13. Spider diagram LSW1 using PSC.

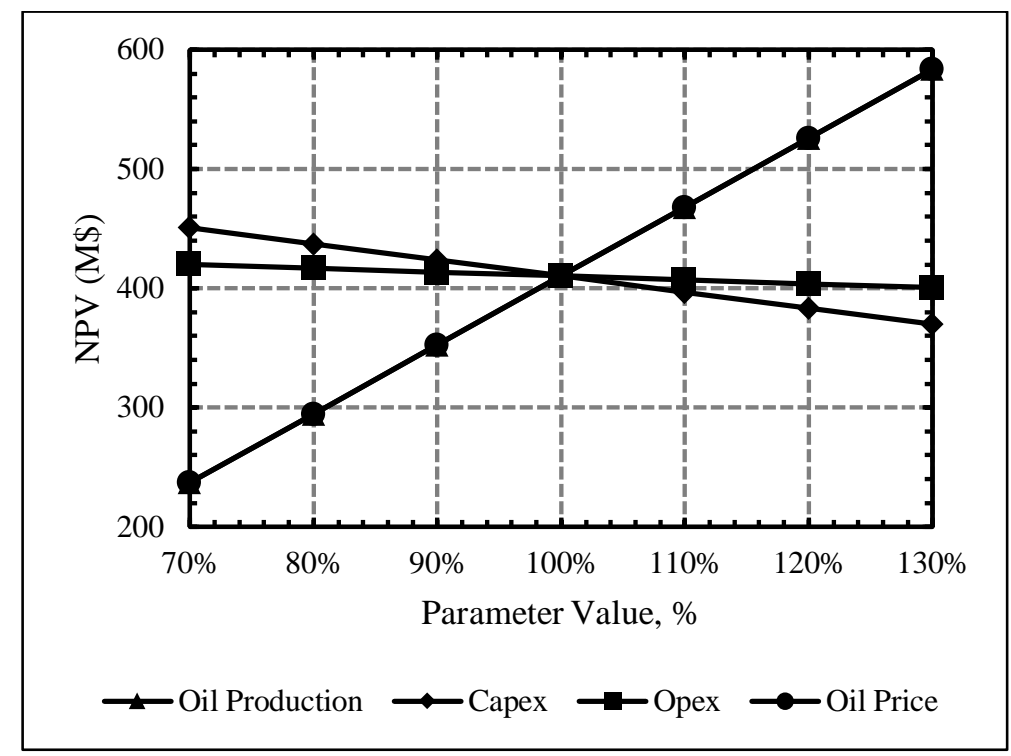

Figure 14. Spider diagram LSW1 using Gross Split.

\section{CONCLUSIONS}

In summary, this study can be concluded that additional investments in all the cases using PSC scheme are not resulting in higher revenue for the Contractor. Meanwhile in LSWI implementation using Gross Split is more profitable than PSC due to additional split in Gross Split resulting in higher production share for Contractor. Production profile of Field $\mathrm{X}$ is not suitable for cost recovery mechanism causing unrecovered cost. The parameters that affects NPV the most in all PSC cases are the oil production and oil price. On the other hand, in Gross Split cases, the oil production is the parameter that affects NPV the most, followed by oil price. One of the ways for incentivizing EOR implementation in Indonesia is giving additional economic benefit in the fiscal regime for the Contractor. Gross Split scheme, as the newest fiscal regime in Indonesia's oil and gas upstream industry, have the incentives for Contractor implementing EOR in Indonesia by giving additional $4 \%$ split. 


\section{REFERENCES}

Akhmetgareev, V., \& Khisamov, R. (2015). 40 years of Low-Salinity Waterflooding in Pervomaiskoye Field, Russia: Incremental Oil. SPE European Formation Damage Conference and Exhibition, 1-27. https://doi.org/10.2118/174182-ms

Dang, C. T. Q., Nghiem, L., Nguyen, N., Chen, Z., \& Nguyen, Q. (2015). Modeling and Optimization of Low Salinity Waterflood. SPE Reservoir Simulation Symposium, 1, 55-73. https://doi.org/10.2118/173194-ms

Dang, C. T. Q., Nghiem, L., Nguyen, N. T. B., \& Chen, Z. (2015). Practical Concerns and Principle Guidelines for Screening, Implementation, Design, and Optimization of Low Salinity Waterflooding. SPE Western Regional Meeting 2015: Old Horizons, New Horizons Through Enabling Technology, 192-221. https://doi.org/10.2118/174008-ms

Dang, C. T. Q., Nghiem, L. X., Chen, Z., \& Nguyen, Q. P. (2013). Modeling Low Salinity Waterflooding: Ion Exchange, Geochemistry and Wettability Alteration. SPE Annual Technical Conference and Exhibition, 6, 4302-4323. https://doi.org/10.2118/166447-ms

Hakiki, F., Aditya, A., Ulitha, D. T., Shidqi, M., Adi, W. S., Wibowo, K. H., \& Barus, M. (2017, October 17). Well and Inflow Performance Relationship for Heavy Oil Reservoir under Heating Treatment. SPE/IATMI Asia Pacific Oil \& Gas Conference and Exhibition. https://doi.org/10.2118/186187-ms

Hakiki, F., Maharsi, D. A., \& Marhaendrajana, T. (2015). Surfactant-Polymer Coreflood Simulation and Uncertainty Analysis Derived from Laboratory Study. Journal of Engineering and Technological Sciences, 47(6), 706-725. https://doi.org/10.5614/j.eng.technol.sci.2015.47.6.9

Hidayat, F., Erfando, T., \& Maulana, B. F. (2018). Spontaneous Imbibition Test of Low Salinity Injection at Low Saline Waxy Crude Carbonate. Journal of Earth Energy Engineering, 7(2), 14-22. https://doi.org/10.25299/jeee.2018.vol7(2).2215

Marhaendrajana, T., Ridwan, M. G., Kamil, M. I., \& Permadi, P. (2018). Wettability Alteration Induced by Surface Roughening During Low Salinity Waterflooding. Journal of Engineering and Technological Sciences, 50(5), 635-649. https://doi.org/10.5614/j.eng.technol.sci.2018.50.5.4

Peraturan Pemerintah Nomor 53 Tahun 2017 Tentang Perlakuan Perpajakan Pada Kegiatan Usaha Hulu Minyak dan Gas Bumi dengan Kontrak Bagi Hasil Gross Split. (2017). Government of Indonesia.

Permen ESDM No 08 Tahun 2017 Tentang Kontrak Bagi Hasil Gross Split. (2017). Kementrian Energi dan Sumber Daya Mineral (ESDM).

Permen ESDM No 52 Tahun 2017 Tentang Perubahan Atas Peraturan Menteri Energi dan Sumber Daya Mineral Nomor 08 Tahun 2017 tentang Kontrak Bagi Hasil Gross Split. (2017). Kementrian Energi dan Sumber Daya Mineral (ESDM).

Pouryousefy, E., Xie, Q., \& Saeedi, A. (2016). Effect of multi-component ions exchange on low salinity EOR: Coupled geochemical simulation study. Petroleum, 2(3), 215-224. https://doi.org/10.1016/j.petlm.2016.05.004

PriceWaterCooper. (2018). Oil and Gas in Indonesia: Investment and Taxation Guide (9th ed.). PwC Indonesia.

Rivet, S., Lake, L. W., \& Pope, G. A. (2010, September 22). A Coreflood Investigation of Low-Salinity Enhanced Oil Recovery. SPE Annual Technical Conference and Exhibition. https://doi.org/10.2118/134297-MS

Roach, B., \& Dunstan, A. (2018). The Indonesian PSC: the end of an era. The Journal of World Energy Law \& Business, 11(2), 116-135. https://doi.org/10.1093/jwelb/jwy001

Shehata, A. M., Kumar, H. T., \& Nasr-El-Din, H. A. (2016, June 13). New Insights on Relative Permeability and Initial Water Saturation Effects During Low-Salinity Waterflooding for Sandstone Reservoirs. SPE Trinidad and Tobago Section Energy Resources Conference. https://doi.org/10.2118/180874-MS

Sparrow, B., Ebsary, A., Mandel, D., \& Man, M. (2018). An Advanced Electrochemical System for EOR Produced Water Desalination and Reduced Polymer Consumption. SPE Symposium on Improved Oil Recovery, 2018-April. https://doi.org/10.2118/190272-ms 